oides; the second, by the same fossils, but without $R h$. Meyendorfi, and"with two additional species of Spirifera ( $S$. disjuncta and $S$. lenticula); the third has yielded only these two Spirifers, and Str. productoides, while the fourth contains also Atrypa reticutaris and Orthis striatula. Among the Devonian rocks of Central Russia, which consist only of limestones, $M$. Venukoff tries to establish the following four subdivisions the Voronesh marls and limestones characterised by the presence of Spirifera Anosoffi, together with Atrypa reticularis, Strophalosia productoines, several Orthoceratites and Corals, the Elets ber's, where $S p$. disjuncta, and a variety of $S p$. Archiaci replace $S p$. Aanosoffi, the other leading fossils being: Rhynchonella livonica, Athyris concentrica, Productus subaculeatus, $P$. membranus, Strophalosia productoides, Streptorhynchus crenistria (umbraculum), Pleurotomaria, Euomphalus, \&c. The intermediate beds between these two groups are especially rich in corals (Aulopora serpens, Cyathophyllum ceratites, Syringopora abdita, S. tabulata, species of Stromatopora, \&c.). The Elets beds are covered with a series of limestones characterised by the presence of Arca orcliana, and these last are followed by the well-known group of Murrevuya (in Ryazan) which constitutes a passage between the Devonian and Carboniferous systems. 'The correlation of the subdivisions of the deposits of the Devonian groups of North-Western with those of Central Russia, and of both with those of Westcrn Europe, is beset with difficulties. Still it appears that the limestones of Elets and Voronesh, as also those of the Duna (especially since M. Antonowitsch's researches), are comparable with the Stringocephalus group of the Eifel and Nassau; some resemblance may also be traced between the Elets and Voronesh limestones and the higher parts of the Middle and Lower members of the Upper Devonian system of England. They may likewisc represent the "Frasnien" subdivision of the Upper Devonian series of the Boulonnais. Regarding the Lower Devonian Sandstones of Russia, Murchison's correlation of them with the [Lower] Old Red Sandstone of Caithness and Elgin remains unshaken. The break between these sandstones and the Silurian deposits which they cove sccms also to be confirmed. As to the Devonian rocks of Poland, it appears from M. Mikhalsky's researches (Izzestia of the Geol. Committee, 1883) that the Lower, Middle, and Upper Devonian divisions of Western Europe are found there, the Upper being akin to the Rhynchonella cuboides group of the Eifel. Again, on the other side of the country the discovery on the eastern slope of the Ural of a Clymenia closely akin to the $C$. annulatiand the $C$. spinosa (1zvestia, 1884,4 ) is a fresh con. firmation of the likeness of the Ural Devonian rocks to those of Western Europe. According to M. Tschernyshey the limestones of the western s!ope of the Middle Ural chain belong to the Lower Devonian, those of the Byclaya River (Izvestia, I885, 3) belonging to its lower subdivisions.

\section{SCIENCE IN BOHEMIA}

THE Royal Rohemian Society of Sciences celebrated, on December 6 of last year, the hundredth year of its public existence. Occasion has been taken to issue some special pubications, comprising a historical sketch of the Society and a resumé of the principal researches, a list of all papers, and another of members, since the commencement. The Society originated in a private one for study of science and history started in I 770 under the presidency of Ignaz von Born, who was not only an able scientist of the time, but an ardent frecmason (as were many of his fellows). It is a curious fact, throwing light on the aims of this Society, that its publications were all in German, not in Latin, the usual scientific medium in Bohemia at that time. No one thought of using Bohemian for science. Noze a considerable portion of papers appear in Bohemian, not always accompanied by a German részmné, through which some are rendered more accessible to the average linguist here.

Of the various scientific work recorded in the Abhanalnongen and Sitzungsberichte for $1883^{-84}$ we may first notice that on fossil forms. The sponges of the Bohemian chalk formation, as represented in the Prague Museum, are being gone through by M. Pocta. In the new method of studying such remains, special weight is attached to inner structure, the outer form being re garded as of secondary importance; and following this course M. Pocta contributes the first two portions of a careful and finely-illustrated monograph dealing with the Hexactinellide? and
Lithistida, two of the seven orders of Zittel's classification. M. Pocta describes elsewhere the varieties of isolated sponge spicules met with in the chalk. Some sponge remains from the Lower Silurian strata of Bohemia resemble (according to M. Feistmantel) the species Acanthospongia Siluriensis, described by MacCoy in $\mathrm{r} 846$, and found at Cong, near Galway. We further notice accounts of fossil flora of the ianthracite formation in Central Bohemia (M. Kusta), and of remarkable stem remains of $4 \mathrm{rau}$ caroxylon from the same (M. Feistmantel), \&c. M. Novak shows from Bohemian trilobites how the form and markings of the hypostome offer good generic characters which may be taken as decisive where the other parts of the body agree.

Among interesting fossils brought before the Society is a scorpion from the "Moravia" coal-pit at Rakonitz. This is one of the little known order of Pedopalpi, and is the first fossil representative of a still living genus, Thalyphonus, and probably of the order. Its great similarity to present forms is noteworthy, showing persistence of type in this genus from the Carboniferous period. The same pit has yielded four new spiders, and the number of known Palæozoic arachnida is now (according to M. Kusta) 34. A fossil cockchafer was found in a mass of Tertiary quartz received from France at a millstone manufactory in Praguc. The body stood nearly frec in an oval hollow of the stone, doubtless corresponding to the cocoon. M. Fric has sent it to the Jardin des Plantes, Paris.

From a chemical examination of the dark colouring matter of ebony, M. Belohoubek concludes that it is to be regarded as coal, and the case is a striking one, as being that of carbonisation of plant material occurring physiologically in a living plant. The aithor not having sufficient young ebony could not exactly determine the mother-substance, $M$. Celakovosky finds in certain anamorphoses of the ovulum of Raphanus sativus, $\mathrm{L}$., and in abnormal leaves of Croton, evidence in support of the foliolar theory of the ovulum. M. Palacky furnishes two instalments of his valuable, though necessarily incomplete and tentative sketch of the geographical distribution of plants. 'The formation of serial buds is studied by M. Velenovsky. M. Hansgirg extends the knowledge of Bohemian algæe (imperfectly studied hitherto), and there are yearly reports on the additions to Bohemian botany.

The organs of excretion of Hirudinete are to be regarded (according to M. Vijdovsky) as modified "segmental organs" of the Oligochata; as the former worms may be considered as Oligochrta degenerate through parasitism. The same author furnishes an account of the freshwater sponges of Bohemia; he finds five well-characterised species with some varicties belonging to the three sub-genera, Eusponyilla, Ephydatia, and Trochospongilla. Of freshwater Bryozoa M. Kafka finds in Bohemia thirtcen species, two of them new. M. Bayer shows how widely apart Pelobates and Bombinator are in the structure of their slieleton, and offers a new classification of the Anoura.

Considering the nature of steel-hardening from the electrical standpoint, in connection with the corresponding behaviour of some silver alloys, MM. Strouhal and Barus arrive at the result that neither the mechanical nor the chemical hypothesis as to steel hardening suffices alone to explain the phenomena, and, while the proportion of carbon is the principal factor for determining the behaviour of steel, this behaviour must be explained by a combination of chemical and mechanical infuences. The authors offer a definition of steel on the basis of the electrical behaviour of iron with increasing proportion of carbon. M. Kolacek makes a contribution to the theory of the Gramme machine. M. Seydler investigates the application of the principle of energy to the pondero-motive and electro-motive actions of the electric current, also the theory of tension of electrostatic phenomena from the standpoint of the theory of elasticity. There are various papers in mathematics, crystallography, \&c., which we must not stop to notice. Tables of rainfall at different stations of Bohemia are furnished by M. Stodnicka.

To this brief account, indicating some directions of recent Bohemian science, we will add a word about the great work of Barrande. That eminent geologist, who died on October 5, I883, left his collections, \&c., to the Bohemian Museum; he also left directions and funds for the completion of his "Système Silurien du Centre de la Bohème," of which twenty-two volumes had appeared between 1852 and 1881. Drs. Waagen and Noval now undertake, at Barrande's request, the further work required. The text and plates relating to the Gastcropods and Echinoderms were found in a nearly finished statc, but the Polyps, Graptoliths, and Bryozoa have still to be worked ont for 
the most part. Four volumes will thus be added to this remarkable work, making in all twenty-six, with 2000 plates of illustrations.

\section{UNIVERSITY AND EDUCATIONAL INTELLIGENCE}

THE Bristol Merchant Venturers' School of Science, Technology, and Commerce, erected at a cost of nearly 50,000l., to replace the old Trade and Mining School, was formally dedicated by the merchants to the city on Saturday, when their handsome gift, including the complete charge of the school, estimated at roool. a year, was received by the Mayor on behalf of the citizens. After the Trade and Mining School was handed over to the Colston Trust by the Endowed Schools Commissioners, this science school, which had already won a very distinguished position in the country, made such rapid progress that the building was soon found inadequate for the 500 scholars attending it, and the Merchant Venturers, who constituted the chief part of the governing body known as the Colston Trust, determined to build a new school on the plan of the newest and best equipped English and foreign school, with the best-known methods and appliances for science and art instruction. Finding that the Colston Trust funds assigned for the purpose were inadequate to the demand of such a large building, they undertook the entire charge, so that the scholastic institution will henceforth be known as the Bristol Merchant Venturers' School. Sir Frederick Bramwell, C.E., Chairman of the Council of the City Guilds Institution for the Advancement of Technical Education, the Mayor and High Sheriff of Bristol, the Bishop of Gloucester and Bristol, Mr. Samuel Morley, M.P., Mr. Lewis Fry, M.P., Col. Donnelly, Capt. Abney, and others took part in the inaugural ceremony, which was prefaced by a luncheon given by the master of the Society, Mr. R. W. Butterworth, at the Merchant Venturers' Hall. After the luncheon the party repaired to the new schools, and the opening ceremony took place in the examination hall. The Master ( $\mathrm{Mr}$. Butterworth) presided, and in opening the proceedings gave a history of the growth of the old Trade School and its development into the present great establishment. The Master then called upon Sir Frederick Bramwell to declare the building open. Sir Frederick Bramwell said he thought that he might safely say that almost by universal agreement the training to be given in schools such as that was held to be a training that ought to be given, and was a national benefit and blessing. That meeting, he said, was not to initiate something new, for, as had been said, the work had gone on for thirty years ; it was not to mark a birth, but to mark progress; not the full development, or anything like it, but a stage-for they would hope that not many years would elapse before an andience as numerous and as earnest as that he saw before him would meet in Bristol to celebrate some further marked step in the development of technical education in the city. What was the object in giving this technical education? The primary object was to enable men and women to earn their living better than they could otherwise do. The primary object of such education was to teach men engaged in industrial pursuits to conduct them in a manner which would redound to their happiness and material prosperity, and this would redound to the prosperity and welfare of the whole nation. A man instructed as he would be there would be enabled to carry on his industry in a totally different manner from those who had to begin the battle of life fifty years ago. At that time they had to profit by what could be taught them derived from experience, but without understanding the principle on which the things depended. They should remember the great things which for the first sixty years of this century were done by men who had not the advantage of technical education. But when a man had that advantage he was enabled to look at the experience of the past in a totally different manner, because he knew the principles on which that experience was based, and knew when it was applicable or inapplicable. Whatever his determination, the Englishman was badly weighted in his struggle with his foreign competitor if the latter had the means of applying science to his industry when the former had not. In London they were doing good work of this sort, one of the branches being technological examination, and during the past three years the number of those that came up more than doubled-from rgoo to 3900 . That increase did not arise from the governing body relaxing the examination; on the contrary, they thought it right to add to he stringency of the examination. So the best judges of all, the very men whom they wished to instruct, themselves proved that they valued this instruction. It could not be said that this was a question where they were endeavouring to force on an unwilling people the advantages of education the value of which they did not recognise; and thus they had the encouragement arising from appreciation of their efforts.

Mr. Arthur Smithells, B.Sc. (London), assistant lecturer and demonstrator in chemistry at the Owens College, Manchester, has been elected to the Professorship of Chemistry at the Yorkshire College, Leeds, rendered vacant by the appointment of Dr. Thorpe to the Chair of Chemistry in the Royal School of Mines and Normal School of Science, South Kensington.

\section{SCIENTIFIC SERIALS}

Fournal of Franklin Institute, No. 713, May.-Prof. C. F. Himes, actinism. A lecture delivered at the Philadelphin Electrical Exhibition, giving a succinct account of modern investigations. $-F$. E. Ives, isochromatic photography. Describes his blue-myrtle chlorophyll process. -C. J. Hexamer, fire hazards in textile mills. Deals with relative risks of cotton, wool, and shoddy of various qualities. -W. B. Le Van, economy in the use of high-pressure steam. Describes a new high-pressure boiler.-Prof. Pliny E. Chase, further experiments in weather forecast. Of interest to meteorologists. - Prof. E. J. Houston, glimpses of the International Electrical Exhibition, No. 7, Drawbaugh's telephonic inventions. Description and drawings of the instruments of this notorious person.

No. 7I4, June.-Dr. Persifor Frazer, the World's Industrial and Cotton Centennial exposition. Gossip about the New Orleans Exhibition.-Prof. J. Burkitt Webb, a simple form of draught gauge; a simple instrument for measuring the decrease of pressure in a flue directly by scales. - Dr. Werner Siemens, on the electromotive action of illuminated selenium, discovered by Mr. Fritts. In this communication, which is translated from the German, Dr. Siemens describes as being entirely new and scientifically of the most far-reaching importance, the phenomena discovered by Mr. Fritts, which were, at Philadelphia, condemned by Prof. Rowland as unworthy of being brought before the Physics section of the American Association. Dr. Siemens agrees with. Mr. Fritts that in his experiments there is a direct conversion of the energy of light into electrical energy. $-E$. L. Corthell, the Tehuantepec Ship Railway.-Prof. E. J. Houston, facsimile telegraphy.Appended to this number are the reports of the examiners of the Philadelphia Electrical Exhibition on electric arc lamps, and on carbons for arc lamps.

Annalen der Physik und Chemie, xxiv. No. 4, April.-Prof. F. Melde, experimental researches in acoustics. Gives account of new experiments with a phonic wheel and other electromagnetic means of exciting vibrations.-G. Tammann, on the vapour-pressure of salt solutions. Gives many hundreds of determinations of lowering of pressure of aqueous vapour by addition of some soluble salt. The author concludes that for a given salt the product of the relative pressure-reduction into the volume of the solution relatively to that of the water it contains is a constant. Exceptions are attributed to polymerisation. - Prof. W. von Bezold, on current-figures in liquids. The method consists in observing the forms which result from putting aniline dyes (such as are used for ink in hectograph) upon the liquids. The present paper deals with the internal currents set up by differences of temperature prorluced by surrounding with a ring of ice, \&c. The figures are curious and instructive.-Prof. E. Kittler, on measurement of strength of currents. Describes the method of taking strength of currents by measuring potential when the current is passed through a known resistance.--Prof. G. Quincke, electrical researches, No. xi. This series deals with the constants of electromagnetic rotation. For sodium light, Quincke finds the constant for bisulphide of carbon to be $4.409^{\prime}$ at $2 \mathrm{I}^{\circ} \mathrm{C}$. Becquerel found $4^{\prime} 63^{\prime}$ at $0^{\circ}$, and Lord Rayleigh and Mrs. Sidgwick found $4^{\prime} 2002^{\prime}$ at $\mathrm{r}^{\circ}$. Quincke gives tables of statistical results for other liquids, agreeing in the main with those of Perkin and of Becquerel.-A. Gockel, on the relation of the Peltier-heat to the efficiency of galvanic elements. A discussion of the work of Braun, Chaperon, Czapsky, Bouty, and others, with redeterminations. - W. Herman Schultze, on the reaction between two mutually perpendicular magnetic distributions. Very careful experiments confirm Siemens's result that longitudinal magnetism 